\title{
Synthesis and copolymerisation of fluorinated monomers bearing a reactive lateral group. Part $21^{*}$. Radical copolymerisation of vinylidene fluoride with 2-hydroperfluorooct-1-ene'.
}

B. Otazaghine, L. Sauguet and B. Ameduri

Laboratory of Macromolecular Chemistry, UMR-CNRS 5076, Ecole Nationale Supérieure de Chimie de Montpellier, 8 rue de l'Ecole Normale, 34296 Montpellier Cedex 05, France

\begin{abstract}
The synthesis and the radical copolymerisation of 2-hydroperfluorooct-1-ene (HPO) with vinylidene fluoride (VDF), initiated by tertio-butyl peroxypivalate (TBPPI) at $75^{\circ} \mathrm{C}$ are presented. That fluorinated alkene (HPO) was synthesised in two steps starting from the thermal or redox telomerisation of VDF with $\mathrm{C}_{6} \mathrm{~F}_{13} \mathrm{I}$ (after purification of the monoadduct compound by rectification) followed by a dehydroiodination in the presence of various alkalies. Their influences are discussed toward the yield of the reaction. The compositions of the resulting random-type copolymers were calculated by means of ${ }^{19} \mathrm{~F}$ NMR spectroscopy and allowed one to quantify the respective amounts of each monomeric unit in the copolymer. From the Tidwell and Mortimer method, the reactivity ratios $\left(r_{i}\right)$ of both comonomers for this copolymerisation were determined showing a higher incorporation of $\mathrm{VDF}: \mathrm{r}_{\mathrm{VDF}}=12.0 \pm 3.0$ and $\mathrm{r}_{\mathrm{F} 2 \mathrm{C}=\mathrm{CHC} 6 \mathrm{~F} 13}=0.9 \pm 0.4$ at $74^{\circ} \mathrm{C}$.
\end{abstract}

\section{KEY WORDS}

Vinylidene fluoride, 2-hydroperfluorooct-1-ene, radical copolymerisation, NMR spectroscopy, reactivity ratio

\footnotetext{
* Part 20, see ref.[38]

$\uparrow$ Presented at the 16th International Symposium in Fluorine Chemistry, Durham (UK), July 16-21, 2000.
} 


\section{GRAPHICAL ABSTRACT}

\section{Synthesis and copolymerisation of fluorinated monomers bearing a reactive lateral group. Part 21. Radical copolymerisation of vinylidene fluoride with 2- hydroperfluorooct-1-ene.}

B. Otazaghine, L. Sauguet and B. Ameduri

Laboratory of Macromolecular Chemistry, UMR-CNRS 5076, Ecole Nationale Supérieure de Chimie de Montpellier, 8 rue de l'Ecole Normale, 34296 Montpellier Cedex 05, France

The synthesis of 2-hydroperfluorooct-1-ene (HPO) monomer and its radical copolymerisation with vinylidene fluoride (VDF) was achieved :

$$
\begin{array}{cc}
\mathrm{CH}_{2}=\mathrm{CF}_{2} & +\mathrm{CF}_{2}=\mathrm{CH}-\mathrm{C}_{6} \mathrm{~F}_{13} \\
\text { VDF } & \text { HPO }
\end{array}
$$

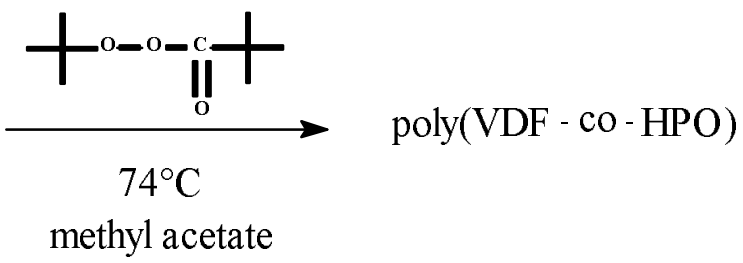

methyl acetate

The kinetics of copolymerisation of VDF with $\mathrm{F}_{2} \mathrm{C}=\mathrm{CHC}_{6} \mathrm{~F}_{13}$ (HPO) led to the determination of the reactivity ratios : $\mathrm{r}_{\mathrm{VDF}}=12.0 \pm 3.0$ and $\mathrm{r}_{\mathrm{F} 2 \mathrm{C}=\mathrm{CHC} 6 \mathrm{~F} 13}=0.9 \pm 0.4$ at $74^{\circ} \mathrm{C}$. 


\section{Introduction}

Fluorinated copolymers [1-3] are attractive for their exceptional properties and, in spite of their high price, show a lower crystallinity-rate than that of the fluorohomopolymers [4]. As a matter of fact, the appropriate choice of the comonomer enables one to bring complementary properties [3] : cyclohexyl group for the solubility, hydroxy and epoxy functions for curability, carboxylic group for adhesion, amido bridge for mechanical properties and perfluorinated group for enhanced surface properties.

We have found interesting to investigate that last property and especially that of poly(vinylidene fluoride), PVDF. Although many copolymerisations of VDF with a wide variety of hydrogenated [5,6] or fluorinated comonomers [3] have already been successfully achieved, that of VDF with $2 \mathrm{H}$-perfluoroalkenes have been scarcely investigated. To our knowledge, the only survey concerns the use of 2-hydropentafluoropropylene (PFP) yielding original fluorinated copolymers studied by the $3 \mathrm{M}$ [7] and the Montedison [8] companies to circumvent VDF / hexafluoropropylene elastomers (called Daiel ${ }^{\circledR}$, Tecnoflon ${ }^{\circledR}$, Viton ${ }^{\circledR}$ or Fluorel $\left.^{\circledR}\right)[1,9-12]$. However, these former ones did not find the same fate as that of the latter ones.

In an academic point of view, Usmanov et al. [13] studied the kinetics of copolymerisation of VDF and PFP initiated by $\gamma$ rays at various temperatures and showed that VDF was more incorporated in the copolymer than PFP. It was thus worth increasing the fluorinated chain length to enable the resulting copolymers to show improved surface characteristics. To our knowledge, such an opportunity has never been reported in the literature. Hence, the objective of this article deals with the synthesis of 2-hydroperfluorooct1-ene (HPO) and its radical copolymerisation with VDF. 


\section{Results and discussion}

The radical copolymerisation of vinylidene fluoride (VDF) with 2-hydroperfluorooct-1-ene (HPO) was carried out in methyl acetate solution, initiated by tertio-butyl peroxypivalate as follows :

\section{Insert Scheme 1}

Before investigating the kinetics of that copolymerisation the synthesis of HPO was optimised.

\section{Synthesis of 2-hydroperfluorooct-1-ene (HPO).}

The preparation of this fluoroalkene was achieved in a two-step procedure starting from a telomerisation reaction [3] of VDF with 1-iodo-perfluoro-n-hexane followed by the dehydroiodination of the monoadduct $\left(\mathrm{C}_{6} \mathrm{~F}_{13} \mathrm{CH}_{2} \mathrm{CF}_{2} \mathrm{I}\right)$, as shown in Scheme 2 .

\section{Insert Scheme 2}

The first step $[14,15]$ can be initiated either thermally (from $180^{\circ} \mathrm{C}$ ) leading to a telomeric distribution that can be made narrower with a higher temperature and with a slight excess of $n-\mathrm{C}_{6} \mathrm{~F}_{13} \mathrm{I}$, or in the presence of a redox catalyst $\left(\mathrm{FeCl}_{3} / \mathrm{Ni}\right.$ or $\left.\mathrm{CuCl}\right)$ yielding monoadduct selectively $\left(\mathrm{C}_{6} \mathrm{~F}_{13} \mathrm{CH}_{2} \mathrm{CF}_{2} \mathrm{I}\right)$. From both these initiating systems, the $\mathrm{n}-\mathrm{C}_{6} \mathrm{~F}_{13} \mathrm{I}$ conversions were quantitative or $65 \%$, respectively.

The second step was already reported by different teams : pioneered by Fields and Haszeldine [16] in 1964, it was also studied by Apsey et al. [17], by Saloutina et al. [18], and then by Hung and Schmiegel [19]. However, these authors did not describe the influence of various bases onto the conversion of the iodinated product and the amount of HPO. It was thus worth revisiting this second step to optimise this reaction.

Table 1 summarises the obtained results when various alkalies $\left(\mathrm{KF} / \mathrm{Al}_{2} \mathrm{O}_{3}, \mathrm{~K}_{2} \mathrm{CO}_{3} / \mathrm{BuCN}\right.$, triethylamine, tributylamine and pyridine) were used in almost similar conditions. These dehydroiodination reactions were monitored by gas chromatography and confirmed by ${ }^{1} \mathrm{H}$ and ${ }^{19}$ F NMR (Figure 1). Indeed, in the ${ }^{1} \mathrm{H}$ NMR spectrum, the signal assigned to the methylene 
group, located in the $\beta$ position about the iodide atom for the telomer precursor, centered at $3.5 \mathrm{ppm}$, underwent a low field shift to $4.8 \mathrm{ppm}$ with a modification of its multiplicity when the dehydroiodination occured. Beside gas chromatography, the conversion rate of the reaction could thus be assessed from the ${ }^{1} \mathrm{H}$ NMR spectra via the ratio of the integrals of both these signals.

\section{Insert Table 1}

$\underline{\text { Insert Figure } 1}$

The ${ }^{1} \mathrm{H}$ NMR spectrum shows the quantitative conversion of $\mathrm{C}_{6} \mathrm{~F}_{13} \mathrm{CH}_{2} \mathrm{CF}_{2} \mathrm{I}$ by the absence of the $-\mathrm{C}_{2}{ }_{2} \mathrm{CF}_{2} \mathrm{I}$ signal at $3.5 \mathrm{ppm}$ and the presence at $4.7 \mathrm{ppm}$ of the $-\mathrm{C} \underline{\mathbf{H}}=\mathrm{CF}_{2}$ signal. The ${ }^{19} \mathrm{~F}$ NMR spectrum (Figure 1) shows the absences of signal at -38.2 assigned to the difluoromethylene groups in the $\alpha$ position about the iodide in the precursor. It also exhibits the complex signals centered at $-61.2 \mathrm{ppm}$ and $-72.4 \mathrm{ppm}$, assigned to both fluorine atoms of $\mathrm{CH}=\mathrm{C}_{2} \underline{2}$ end group.

The ${ }^{13} \mathrm{C}$ NMR spectrum (Figure 2) exhibits the characteristic signals of the expected product : at $73.4 \mathrm{ppm}$ the doublet of doublets of doublets corresponding to $\mathrm{C}_{6} \mathrm{~F}_{13} \underline{\mathrm{CH}}=\mathrm{CF}_{2}\left({ }^{2} \mathrm{~J}_{\mathrm{CF}}=35.9\right.$ $\mathrm{Hz},{ }^{2} \mathrm{~J}_{\mathrm{CF}}=27.6 \mathrm{~Hz}$ and ${ }^{2} \mathrm{~J}_{\mathrm{CF}}=12.1 \mathrm{~Hz}$ ) ; the 105 to $130 \mathrm{ppm}$ zone is assigned to the $\underline{\mathrm{CF}}_{2}$ of the perfluorinated chain and the triplet of triplets located at $160.2 \mathrm{ppm}$ is attributed to the $\mathrm{CH}=\underline{\mathbf{C F}}_{2}$ end group $\left({ }^{1} \mathrm{~J}_{\mathrm{CF}}=294.2 \mathrm{~Hz}\right.$ and $\left.{ }^{3} \mathrm{~J}_{\mathrm{CF}}=7.0 \mathrm{~Hz}\right)$.

\section{Insert Figure 2}

\section{Copolymerisation of VDF with 2-hydroperfluorooct-1-ene (HPO)}

\subsection{Copolymerisation of VDF with the 2-hydroperfluorooct-1-ene}

The radical copolymerisations of VDF with the 2-hydroperfluorooct-1-ene $\left(\mathrm{C}_{6} \mathrm{~F}_{13} \mathrm{CH}=\mathrm{CF}_{2}\right)$ were carried out in Carius tube with tertiobutyl peroxypivalate as the initiator ([tBu-OO-CO$\mathrm{tBu}]_{0} /\left([\mathrm{VDF}]_{0}+\left[\mathrm{C}_{6} \mathrm{~F}_{13} \mathrm{CH}=\mathrm{CF}_{2}\right]_{0}\right)=1 \mathrm{~mol} \%$ ) in methyl acetate as the solvent.

After reaction, the copolymers were precipitated in cold pentane and analysed by ${ }^{1} \mathrm{H}$ and ${ }^{19} \mathrm{~F}$ NMR spectroscopy. The physical properties of the materials depend on the proportions between VDF and $\mathrm{C}_{6} \mathrm{~F}_{13} \mathrm{CH}=\mathrm{CF}_{2}$ and varied from wax to powder. They were usually soluble in acetone and in dimethylformamide (DMF) or dimethylacetamide (DMAc) for high proportions in VDF. 


\section{2.a Copolymerisation kinetics}

Seven copolymerisations were performed (Table 2) for 3 hours at $74^{\circ} \mathrm{C}$ from initial $[\mathrm{VDF}]_{0} /[\mathrm{HPO}]_{0}$ molar ratios ranging between $11.8 / 88.2$ and 87.1/12.9.

\section{$\underline{\text { Insert Table } 2}$}

Due to the very wide field of the ${ }^{19} \mathrm{~F}$ versus the ${ }^{1} \mathrm{H}$ field and because of the overlapping of the signals of methylene groups of VDF and proton of HPO in the copolymers, the amounts of both comonomeric units in the copolymers were determined by ${ }^{19} \mathrm{~F}$ NMR only. Figure 3 represents the ${ }^{19} \mathrm{~F}$ NMR spectrum of the dried poly(VDF-co-HPO) produced from an initial $[\mathrm{VDF}]_{0} /[\mathrm{HPO}]_{0}$ molar ratio of 87.1/12.9.

\section{Insert Figure 3}

This spectrum can be divided into four distinct zones corresponding to the characteristic signals of each comonomer : first, at $-81 \mathrm{ppm}$ a triplet attributed to the trifluoromethyl end group in the HPO olefin ; from -91 to $-115.7 \mathrm{ppm}$, the peaks assigned to the $\mathrm{CF}_{2}$ that belong to the VDF ; then, the -121 to -127 ppm zone attributed to the perfluorinated chain of HPO olefin. As previously, the signals of each monomer are presented in the spectrum of the copolymer. The assignements of the different signals are listed in Table 3.

\section{$\underline{\text { Insert Table } 3}$}

From the integrals of the characteristic signals in the ${ }^{19}$ NMR spectra, the assessment of the amounts of both comonomeric units in the copolymers is given by the following equation :

$\mathrm{mol} \%$ VDF in the copolymer $=\frac{\frac{\left(I_{-91.0}+I_{-94.8}+I_{-111.2}+I_{-113.7}+I_{-115.7)}\right.}{2}}{\frac{\left(I_{-91.0}+I_{-94.8}+I_{-111.2}+I_{-113.7}+I_{-115.7)}\right)}{2}+\frac{I_{-81.0}}{3}} * 100 \quad$ (equation 1) The results are presented in Table 2 and the composition curve (i.e., the mol. \% of VDF in the copolymer versus that in feed) is shown in Figure 4. 


\section{Insert Figure 4}

For each composition in feed $\left(f_{1}\right)$, the value of the respective composition in the copolymer $\left(F_{1}\right)$ is placed up to the bisector (where $F_{1}=f_{1}$ ), that means that VDF is more reactive than $\mathrm{C}_{6} \mathrm{~F}_{13} \mathrm{CH}=\mathrm{CF}_{2}$ and its incorporation is easier than the longer olefin. From these values and by using the Tidwell and Mortimer method [20], the monomer reactivity ratios were determined. It was found that $r_{\mathrm{VDF}}=12.0 \pm 3.0$ and $\mathrm{r}_{\mathrm{F} 2 \mathrm{C}=\mathrm{CHC} 6 \mathrm{~F} 13}=0.9 \pm 0.4$ at $74^{\circ} \mathrm{C}$. These values can be compared to those of other fluoromonomers able to copolymerise with VDF (Table 4). The traditional method for the determination of relative reactivity of a macroradical to several monomers was used. Indeed, it is common to compare the values $1 / \mathrm{r}_{\mathrm{A}}=\mathrm{k}_{\mathrm{AB}} / \mathrm{k}_{\mathrm{AA}}$ as the ratio of rate constants of crossed propagation to that of propagation $\left(\mathrm{k}_{\mathrm{AA}}\right)$. Thus, the higher the $1 / \mathrm{r}_{\mathrm{A}}$ value, the more able the radical is to react with the second monomer $\mathrm{B}$. Table 4 [13, 21-43] allows one to suggest the following increasing series of relative reactivities of monomers to mum VDF ${ }^{\circ}$ radicals : $\mathrm{F}_{2} \mathrm{C}=\mathrm{CHC}_{6} \mathrm{~F}_{13}<\mathrm{F}_{2} \mathrm{C}=\mathrm{CHCF}_{3}<\mathrm{HFP}<\mathrm{PMVE}<\mathrm{PPVE}<\mathrm{VDF}<\mathrm{TrFE}$ $<$ CTFE (recent value) $\approx \mathrm{BrTFE}<\mathrm{H}_{2} \mathrm{C}=\mathrm{CFCF}_{2} \mathrm{OR}_{\mathrm{F}}<\mathrm{TFE}<\mathrm{F}_{2} \mathrm{C}=\mathrm{CFC}_{3} \mathrm{H}_{6} \mathrm{SCOCH}_{3}<$ $\mathrm{F}_{2} \mathrm{C}=\mathrm{CFC}_{3} \mathrm{H}_{6} \mathrm{OAc}<\mathrm{H}_{2} \mathrm{C}=\mathrm{CHF} \approx \mathrm{CTFE}$ (old value) $<$ ethylene, although numerous kinetics still deserve to be investigated. Since all these radical copolymerisations were not carried out in the same experimental conditions (choice of initiator, solvent, time and temperature), the reactivity ratios were not assessed from the same law of kinetics. So, HPO fluoroolefin has a very low reactivity compared to that of VDF and the copolymers of both these monomers show a better incorporation of VDF.

\section{$\underline{\text { Insert Table } 4}$}




\section{Conclusion}

$\mathrm{C}_{6} \mathrm{~F}_{13} \mathrm{CH}=\mathrm{CF}_{2}$ (HPO) was synthesised from a two step-reaction starting from the radical or redox telomerisation of the vinylidene fluoride (VDF) with $\mathrm{C}_{6} \mathrm{~F}_{13} \mathrm{I}$. Several bases were used to enable the dehydroiodination of $\mathrm{C}_{6} \mathrm{~F}_{13} \mathrm{CH}_{2} \mathrm{CF}_{2} \mathrm{I}$ and sodium chloride gave the best yield of HFO after a total conversion of this VDF monoadduct. The kinetics of radical copolymerisation of VDF with HPO initiated by TBPPI led to the following reactivity ratios : $\mathrm{r}_{\mathrm{VDF}}=12.0 \pm 3.0$ and $\mathrm{r}_{\mathrm{F} 2 \mathrm{C}=\mathrm{CHC} 6 \mathrm{~F} 13}=0.9 \pm 0.4$ at $74^{\circ} \mathrm{C}$ showing that i) $\mathrm{VDF}$ was more reactive than HPO, and ii) the microstructure of the resulting copolymers was composed of PVDF microblocks separated by one HPO unit. Indeed, by comparing the values of reactivity ratios of a wide range of different fluoromonomers, HPO was the least reactive onto macroradical terminated by a VDF extremity. Hence, original PVDFs bearing $\mathrm{C}_{6} \mathrm{~F}_{13}$ side-group were produced, with improved surface properties, under investigation. 


\section{EXPERIMENTAL PART}

\section{Materials}

Vinylidene fluoride (VDF) was kindly offered by Solvay S.A.. Tertiobutyl peroxypivalate (TBPPI) and $\mathrm{C}_{6} \mathrm{~F}_{13} \mathrm{I}$ were generously offered by "La Chalonaise des Peroxydes" (Châlon sur Marne, France) and Atofina (now Arkema, at Pierre Bénite, France). Tributylamine, triethylamine, pyridine and acetonitrile were provided by Aldrich and were used as received. $\mathrm{C}_{6} \mathrm{~F}_{13} \mathrm{CH}_{2} \mathrm{CF}_{2} \mathrm{I}$ was obtained either by thermal or redox telomerisation of VDF with $\mathrm{C}_{6} \mathrm{~F}_{13} \mathrm{I}$ and purified by rectification as described in previous studies $[14,15]$.

\section{NMR Spectroscopy}

The ${ }^{1} \mathrm{H},{ }^{13} \mathrm{C}$ and ${ }^{19} \mathrm{~F}$ NMR were recorded at ambient temperature on Bruker AC 200 and $\mathrm{AC}$ 250 instruments, using deuterated chloroform or acetone as the solvents and TMS (resp. $\mathrm{CFCl}_{3}$ ) as the references for ${ }^{1} \mathrm{H},{ }^{13} \mathrm{C}$ (resp. ${ }^{19} \mathrm{~F}$ ) nuclei. The letters $\mathrm{s}, \mathrm{d}$, $\mathrm{t}$, q and $\mathrm{m}$ stand for singlet, doublet, triplet, quintet and multiplet, respectively. Coupling constants and chemical shifts are given in hertz $(\mathrm{Hz})$ and ppm, respectively. The experimental conditions to record ${ }^{1} \mathrm{H},{ }^{13} \mathrm{C}$ and ${ }^{19} \mathrm{~F}$ NMR spectra were the following : flip angle $90^{\circ}, 30^{\circ}$ and $30^{\circ}$; acquisition time : $4.5 \mathrm{sec}, 2.9 \mathrm{sec}$ and $0.7 \mathrm{sec}$; pulse delay : $2 \mathrm{sec}, 2 \mathrm{sec}$ and $5 \mathrm{sec}$; number of scans : 16, 12000 and 64 , and a pulse width of $5 \mu$ sec for ${ }^{19} \mathrm{~F}$ NMR.

\section{GC analysis}

Gas chromatography (GC) was carried out on Delsi apparatus (330), fitted with an OV1 column, $2 \mathrm{~m} \times 1 / 4$ inch under nitrogen pressure. The injector was maintained at $255^{\circ} \mathrm{C}$ and the detector at $260^{\circ} \mathrm{C}$. The heating program was regulated from $35^{\circ} \mathrm{C}$ to $250^{\circ} \mathrm{C}$, with a heating rate of $10^{\circ} \mathrm{C} \cdot \mathrm{min}^{-1}$. The GC apparatus was connected to a Hewlett Packard (3390) integrator that led to an automatic peak area calculation system.

\section{Synthesis of $\mathrm{C}_{6} \mathrm{~F}_{13} \mathrm{CH}=\mathrm{CF}_{2}$}

Dehydroiodination reactions were carried out in a two necked round bottom flask equipped with a condenser using $\mathrm{K}_{2} \mathrm{CO}_{3} / \mathrm{BuCN}$, triethylamine, tributylamine and pyridine in almost similar conditions (two mole excess of base about $\mathrm{C}_{6} \mathrm{~F}_{13} \mathrm{C}_{2} \mathrm{H}_{4} \mathrm{I}$ were used with triethylamine, tributylamine and pyridine while stoechiometric amount when $\mathrm{K}_{2} \mathrm{CO}_{3} / \mathrm{BuCN}$ was used). 


\section{With $\mathrm{NEt}_{\underline{3}}$}

In a two necked round bottom flask equipped with a condenser containing $16.0 \mathrm{~g}\left(1.5810^{-1}\right.$ mol.) of $\mathrm{NEt}_{3}$, were dropwise added at room temperature and under stirring, $40.04 \mathrm{~g}\left(7.8510^{-2}\right.$ mol.) of $\mathrm{C}_{6} \mathrm{~F}_{13} \mathrm{CH}_{2} \mathrm{CF}_{2} \mathrm{I}$. In the course of the addition of $\mathrm{C}_{6} \mathrm{~F}_{13} \mathrm{CH}_{2} \mathrm{CF}_{2} \mathrm{I}$ into the base, a discoloration of the pink solution and the formation of a yellow solid could be observed. Then, the solution was heated up to $90^{\circ} \mathrm{C}$ for five hours. Hydrochloric acid (0.5098 N) was added to the medium and the olefin was extracted with chloroform. The solution was dried with $\mathrm{Na}_{2} \mathrm{SO}_{4}$ and the solvent removed by distillation. HPO was purified by distillation (B.p. $=$ $108^{\circ} \mathrm{C}$ ) as a colorless liquid.

${ }^{19} \mathrm{~F}$ NMR (acetone $\mathrm{d}^{6}$, ppm) (Figure 1) $\delta:-72.2\left(\mathrm{ddt},{ }^{2} \mathrm{~J}_{\mathrm{FF}}=12.5 \mathrm{~Hz},{ }^{3} \mathrm{~J}_{\mathrm{FH}}=26.7 \mathrm{~Hz},{ }^{4} \mathrm{~J}_{\mathrm{FF}}=5.0\right.$ $\mathrm{Hz}, 1 \mathrm{~F}) ;-73.4\left(\mathrm{dd},{ }^{2} \mathrm{~J}_{\mathrm{FF}}=15.2 \mathrm{~Hz},{ }^{3} \mathrm{~J}_{\mathrm{FH}}=7.7 \mathrm{~Hz}, 1 \mathrm{~F}\right) ;-82.3\left(\mathrm{~m}, \mathrm{C} \underline{F}^{3}-\mathrm{Rf}-\mathrm{CH}=\mathrm{CF}_{2}, 3 \mathrm{~F}\right)$; 108.7 (m, RfC $\left.\underline{\mathbf{F}}_{2} \mathrm{CH}=\mathrm{CF}_{2}, 2 \mathrm{~F}\right) ;-122.4\left(\mathrm{~m}, \mathrm{RfC}_{\underline{\mathbf{F}}} \mathrm{CF}_{2} \mathrm{CH}=\mathrm{CF}_{2}, 2 \mathrm{~F}\right) ;-123.6\left(\mathrm{~m}, \mathrm{C}_{3} \mathrm{~F}_{7} \mathrm{C} \underline{\mathbf{F}}_{2}, 2 \mathrm{~F}\right)$; $-124.5\left(\mathrm{~m}, \mathrm{C}_{2} \mathrm{~F}_{5} \mathrm{C} \underline{\mathbf{F}} \underline{2}, 2 \mathrm{~F}\right) ;-127.3\left(\mathrm{~m}, \mathrm{CF}_{3} \mathrm{CE}_{2}, 2 \mathrm{~F}\right)$.

${ }^{1} \mathrm{H}$ NMR (acetone $\mathrm{d}^{6}, \mathrm{ppm}$ ) $\delta: 4.7$ (ddt, Rf-C프 $=\mathrm{CF}_{2}, 1 \mathrm{H},{ }^{3} \mathrm{~J}_{\mathrm{HFtrans}}=21.7 \mathrm{~Hz},{ }^{3} \mathrm{~J}_{\mathrm{HFcis}}=12.4 \mathrm{~Hz}$, ${ }^{3} \mathrm{~J}_{\mathrm{HF}} \approx 12.4 \mathrm{~Hz},{ }^{4} \mathrm{~J}_{\mathrm{HF}} \approx 2.2 \mathrm{~Hz}$ ).

${ }^{13} \mathrm{C}$ NMR (acetone $\mathrm{d}^{6}$, ppm) (Figure 2) $\delta: 77.0$ (ddd, Rf- $\underline{\mathrm{CH}}=\mathrm{CF}_{2},{ }^{2} \mathrm{~J}_{\mathrm{CF} 1},=35.9 \mathrm{~Hz},{ }^{2} \mathrm{~J}_{\mathrm{CF} 1},=$ $27.6 \mathrm{~Hz},{ }^{2} \mathrm{~J}_{\mathrm{CF} 3}=12.1 \mathrm{~Hz}$ ) ; 105 to 130 (series of triplets, assigned to the different $\underline{\mathbf{C F}}_{2}$ of the perfluorinated chain) ; 160.2 (tt, Rf-CH= $\underline{C F}_{2},{ }^{1} \mathrm{~J}_{\mathrm{CF}}=294.2 \mathrm{~Hz},{ }^{3} \mathrm{~J}_{\mathrm{CF}}=7.0 \mathrm{~Hz}$ ).

\section{$\underline{\text { With } \mathrm{NBu}_{3}}$}

In a two necked round bottom flask equipped with a distillation device were introduced $75.9 \mathrm{~g}$ (4.1 $\left.10^{-1} \mathrm{~mol}\right)$ of $\mathrm{NBu}_{3}$. Under stirring, $110.66 \mathrm{~g}\left(2.210^{-1} \mathrm{~mol}\right.$.) of $\mathrm{C}_{6} \mathrm{~F}_{13} \mathrm{CH}_{2} \mathrm{CF}_{2} \mathrm{I}$ were dropwise added at room temperature. As above, the consumption of $\mathrm{C}_{6} \mathrm{~F}_{13} \mathrm{CH}_{2} \mathrm{CF}_{2} \mathrm{I}$ was checked by the discoloration of the pink solution and the formation of a yellow solid (about 7 hrs). The fluoroolefin was distillated under atmospheric pressure (B.p. $=107^{\circ} \mathrm{C}$ ) as soon as formed.

\section{Copolymerisation of VDF with $\mathrm{C}_{6} \mathrm{~F}_{13} \mathrm{CH}=\mathrm{CF}_{2}$}

The copolymerisation reactions of VDF with $\mathrm{C}_{6} \mathrm{~F}_{13} \mathrm{CH}=\mathrm{CF}_{2}$ were performed in borosilicate Carius tubes (length $130 \mathrm{~mm}$, inner diameter $10 \mathrm{~mm}$, thickness $2.5 \mathrm{~mm}$; for a total volume of $8 \mathrm{~cm}^{3}$ ). After introducing the liquid and solid reactants (initiator, monomer and methylacetate), the tube was tightly connected to a manifold. After five freeze - thaw cycles, 
the adequate VDF amount was trapped in the tube which was cooled with liquid nitrogen under vacuum.

The expected VDF quantity transferred in the tube was introduced from a beforehand calibration curve linking the VDF pressure (bars) versus the trapped weight (grams) of VDF (for example a difference of pressure of 0.66 bar corresponds to 1.000 gram of VDF). The tube was sealed while immersed in liquid nitrogen and left stirred at the chosen temperature for 3 hours. Then, the copolymers were precipitated from cold pentane and analysed by ${ }^{19} \mathrm{~F}$ NMR and ${ }^{1} \mathrm{H}$ NMR spectroscopy. 


\section{References}

[1] J. Scheirs Modern Fluoropolymers, Wiley and sons, New-York, (1997).

[2] G. Hougham, P.E. Cassidy, K. Johns, T. Davidson, Fluoropolymers 2: Properties, Kluvert, New-York, (1999).

[3] B. Ameduri, B. Boutevin Well-architectured fluoropolymers : Synthesis, Properties and Applications. Elsevier, Amsterdam, (2004).

[4] S. Ebnessajjad, Fluoroplastics: Non-Melt Processible Fluoroplastics; The Definitive User's Guide and Databook, Norwich, New-York, Volume 1 (2003).

[5] C. Tournut, Macromolecular Symposia 82 (1994) 99-109.

[6] C. Tournut, P. Kappler, J.L. Perillon, Surface Coatings International 78 (1995) 99-100, 102-103.

[7] A.N. Bolstad (Minnesota Mining and Manufacturing Co.). US 3163628, (1964).

[8] D. Sianesi, G.C. Bernardi, A. Reggio ("Montecatini" Societa Generale per l'Industria Mineraria e Chimica). BE 645894 (1964).

[9] V. Arcella, R. Ferro, "Fluorocarbon Elastomers" in J. Scheirs (ed) Modern Fluoropolymers, Wiley and sons, New-York, Chapt. 2 (1997) 71-90.

[10] A. Van Cleeff, "Fluoroelastomers" in J. Scheirs (ed), Modern Fluoropolymers, Wiley and sons, New-York Chapt. 32 (1997) 597-614.

[11] A.L. Logothetis, Prog. Polym. Sci. 14 (1989) 251-296.

[12] B. Ameduri, B. Boutevin, G. Kostov, Prog. Polym. Sci. 26 (2001) 105-187.

[13] K.U. Usmanov, A.A. Yul'chibaev, N. Mukhamadaliev, T.K. Sarros, Izv. Vys. Uch. Zav., Khim. Khim. Tekhnol. 18 (1975) 464-466.

[14] J. Balague, B. Ameduri, B. Boutevin, G. Caporiccio, J. Fluorine Chem. 70 (1995) 215223

[15] J. Balague, B. Ameduri, B. Boutevin, G. Caporiccio, J. Fluorine Chem. 102 (2000) 253-268.

[16] R. Fields, R.N. Haszeldine, Journal of the Chemical Society, Abstracts (1964) 18811889 .

[17] G.C. Apsey, R.D. Chambers, M.J. Salisbury, G. Moggi, J. Fluorine Chem. 40 (1988) 261-282.

[18] L.V. Saloutina, A.Y. Zapevalovi, Zh. Org. Khim. 29 (1993) 1337-1348.

[19] M.-H. Hung, W.W. Schmiegel (Dupont Dow Elastomers L.L.C., USA). WO, 2001081464 (2001).

[20] P.W. Tidwell, G.A. Mortimer, J. Polym. Sci., Part A: Gen. Pap. 3 (1965) 369-387.

[21] A.D. Sorokin, E.V. Volkova, R.A. Naberezhnykh, Radiats. Khim. 2 (1972) 295-297.

[22] B. Baradie, M.S. Shoichet, Macromolecules 35 (2002) 3569-3575.

[23] J. Guiot, PhD dissertation, University of Montpellier (2003)

[24] R. Souzy, B. Ameduri, B. Boutevin, Macromol. Chem. Phys. 4 (2004) 476-485.

[25] D. Sianesi, G. Caporiccio, J. Polym. Sci. PartA-1 : Polym. Chem. 6 (1968) 335-339.

[26] G. Caporiccio, D. Sianesi, Chimica e 1'Industria (Milan, Italy) 52 (1970) 37-42.

[27] B. Ameduri, G. Bauduin, J. Polym. Sci., Part A: Polym. Chem. 41 (2003) 3109-3121.

[28] T. Yagi, M. Tatemoto, Polym. J. (Tokyo, Japan) 11 (1979) 429-436.

[29] G. Moggi, P. Bonardelli, J.C.J. Bart, J. Polym. Sci., Polym. Phys. Ed. 22 (1984) 357365.

[30] R.E. Dohany, Encycl. Polym. Sci. Technol. 17 (1989) 532-547.

[31] P. Bonardelli, G. Moggi, A. Turturro, Polymer 27 (1986) 905-909.

[32] R.A. Naberezhnykh, A.D. Sorokin, E.V. Volkova, A.V. Fokin, Izv. Akad. Nauk SSSR, Ser. Khim. (1974) 232-233.

[33] G. Moggi, P. Bonardelli, S. Russo, Conv. Ital. Sci. Macromol., 6th 2 (1983) 405-408. 
[34] M.P. Gelin, B. Ameduri, J. Fluorine Chem. (in press).

[35] B. Otazaghine, L. Sauguet, M. Boucher, B. Ameduri, submitted to Eur. Polym. J.

[36] B.M. Ameduri, A. Manseri, M. Boucher (Hydro-Quebec, Can.). WO, 2002050142 (2002).

[37] J. Guiot, B. Ameduri, B. Boutevin, J. Polym. Sci., Part A: Polym. Chem. 40 (2002) 3634-3643.

[38] J. Guiot, M.A. Neouze, L. Sauguet, B. Ameduri, B. Boutevin, J. Polym. Sci., Part A, Polym. Chem. (in press).

[39] B. Ameduri, G. Bauduin, B. Boutevin, G. Kostov, P. Petrova, Macromolecules 32 (1999) 4544-4550.

[40] B. Ameduri, B. Boutevin, G.K. Kostov, P. Petrova, Designed Monomers and Polymers 2 (1999) 267-285.

[41] R. Souzy, J. Guiot, B. Ameduri, B. Boutevin, O. Paleta, Macromolecules 36 (2003) 9390-9395.

[42] S.G. Khodzhaev, F.Z. Yusupbekova, A.A. Yul'chibaev, Sbornik Nauchnykh Trudov Tashkentskii Gosudarstvennyi Universitet im. V. I. Lenina 667 (1981) 34-48 (Chem. Abst. 97,163545).

[43] J. Guiot, B. Ameduri, B. Boutevin, T. Lannuzel, Eur. Polym. J. 39 (2003) 887-896. 


\section{$\underline{\text { Scheme Captions }}$}

Scheme 1: Copolymerisation of VDF with $H P O$ at $74^{\circ} \mathrm{C}$ in methyl acetate initiated with tertio-butyl peroxypivalate.

Scheme 2 : Synthesis of 2-hydroperfluorooct-1-ene(HPO). 


$$
\begin{array}{ccc}
\mathrm{CH}_{2}=\mathrm{CF}_{2}+\mathrm{CF}_{2}=\mathrm{CH}-\mathrm{C}_{6} \mathrm{~F}_{13} & \frac{\prod_{0}}{\mathrm{VDF}} \\
\mathbf{H P O} & \begin{array}{c}
74^{\circ} \mathrm{C} \\
\text { methyl acetate }
\end{array}
\end{array} \text { poly(VDF - co-HPO) }
$$

Scheme 1: Copolymerisation of VDF with $H P O$ at $74^{\circ} \mathrm{C}$ in methyl acetate initiated with tertio-butyl peroxypivalate. 


$$
\begin{aligned}
& \mathrm{C}_{6} \mathrm{~F}_{13} \mathrm{I}+\mathrm{CH}_{2}=\mathrm{CF}_{2} \underset{\Delta}{\stackrel{\text { Step 1 }}{\longrightarrow}} \mathrm{C}_{6} \mathrm{~F}_{13}-\mathrm{CH}_{2}-\mathrm{CF}_{2}-\mathrm{I} \underset{\text { base }}{\stackrel{\text { Step 2 }}{\longrightarrow}} \mathrm{C}_{6} \mathrm{~F}_{13}-\mathrm{CH}=\mathrm{CF}_{2} \\
& \text { VDF } \\
& \text { HPO }
\end{aligned}
$$

Scheme 2 : Synthesis of 2-hydroperfluorooct-1-ene(HPO) 


\section{Table Captions}

Table 1: Experimental conditions and results of the dehydroiodination of $\mathrm{C}_{6} \mathrm{~F}_{13} \mathrm{CH}_{2} \mathrm{CF}_{2} \mathrm{I}$ in presence of various bases.

Table 2 : Monomer/copolymer compositions from the kinetics of radical copolymerisation of VDF with HPO determined by ${ }^{19} \mathrm{~F}$ NMR spectroscopy. Copolymerisation conditions : $[\mathrm{tBu}-\mathrm{OO}-\mathrm{CO}-\mathrm{tBu}]_{0}\left([\mathrm{VDF}]_{0}+[\mathrm{HPO}]_{0}\right)=$ $1 \mathrm{~mol} \% \%, 74^{\circ} \mathrm{C}, 3 \mathrm{hrs}$.

Table $3:{ }^{19} \mathrm{~F}$ NMR assignments of poly(VDF-co-HPO) copolymers.

Table 4: Monomer reactivity ratios for the copolymerisation of $V D F(A)$ with other fluoroalkenes (B) (ethylene and vinyl acetate). 


\begin{tabular}{cccccc}
\hline Base & $\begin{array}{c}\text { Temperature } \\
\left({ }^{\circ} \mathbf{C}\right)\end{array}$ & $\begin{array}{c}\text { Reaction } \\
\text { time } \\
(\text { hours })\end{array}$ & $\begin{array}{c}\text { Conversion } \\
\text { (\%) of } \\
\mathbf{C}_{6} \mathbf{F}_{\mathbf{1 3}} \mathbf{C H}_{\mathbf{2}} \mathbf{C F}_{\mathbf{2}} \mathbf{I}\end{array}$ & $\begin{array}{c}\text { Mol. \% of } \\
\mathbf{C}_{\mathbf{6}} \mathbf{F}_{\mathbf{1 3}} \mathbf{C H}=\mathbf{C F}_{\mathbf{2}}\end{array}$ & $\begin{array}{c}\text { Mol. \% of product } \\
\text { by produc }\end{array}$ \\
\hline $\mathrm{KF} / \mathrm{Al}_{2} \mathrm{O}_{3} / \mathrm{CH}_{3} \mathrm{CN}$ & 80 & 5 & 60 & 72 & 28 \\
$\mathrm{NEt}_{3}$ & 90 & 5 & 80 & 75 & 25 \\
Pyridine & 110 & 5 & 10 & 77 & 23 \\
$\mathrm{~K}_{2} \mathrm{CO}_{3} / \mathrm{BuCN}$ & 125 & 8 & 75 & 33 & 67 \\
$\mathrm{NBu}$ & 120 & 7 & 100 & 86 & 14 \\
$\mathrm{NaCl}$ & 120 & 5 & 100 & 98 & 2 \\
\hline
\end{tabular}

Table 1: Experimental conditions and results of the dehydroiodination of $\mathrm{C}_{6} \mathrm{~F}_{13} \mathrm{CH}_{2} \mathrm{CF}_{2} \mathrm{I}$ in presence of various bases. 


\begin{tabular}{ccc}
\hline Experiment $\mathrm{n}^{\circ}$ & $\begin{array}{c}\text { (mol. \%) VDF in } \\
\text { feed }\end{array}$ & $\begin{array}{c}\text { (mol. \%) VDF in the } \\
\text { copolymer }\end{array}$ \\
\hline 1 & 11.8 & 26.2 \\
2 & 15.2 & 37.8 \\
3 & 31.5 & 69.8 \\
4 & 47.9 & 89.5 \\
5 & 62.0 & 96.5 \\
6 & 75.2 & 97.4 \\
7 & 87.1 & 99.0 \\
\hline
\end{tabular}

Table 2 : Monomer/copolymer compositions from the kinetics of radical copolymerisation of VDF with HPO determined by ${ }^{19}$ F NMR spectroscopy. Copolymerisation conditions : [tBu-OO-CO-tBu $]_{0}\left([V D F]_{0}+[H P O]_{0}\right)=$ $1 \mathrm{~mol} . \%, 74^{\circ} \mathrm{C}, 3 \mathrm{hrs}$. 


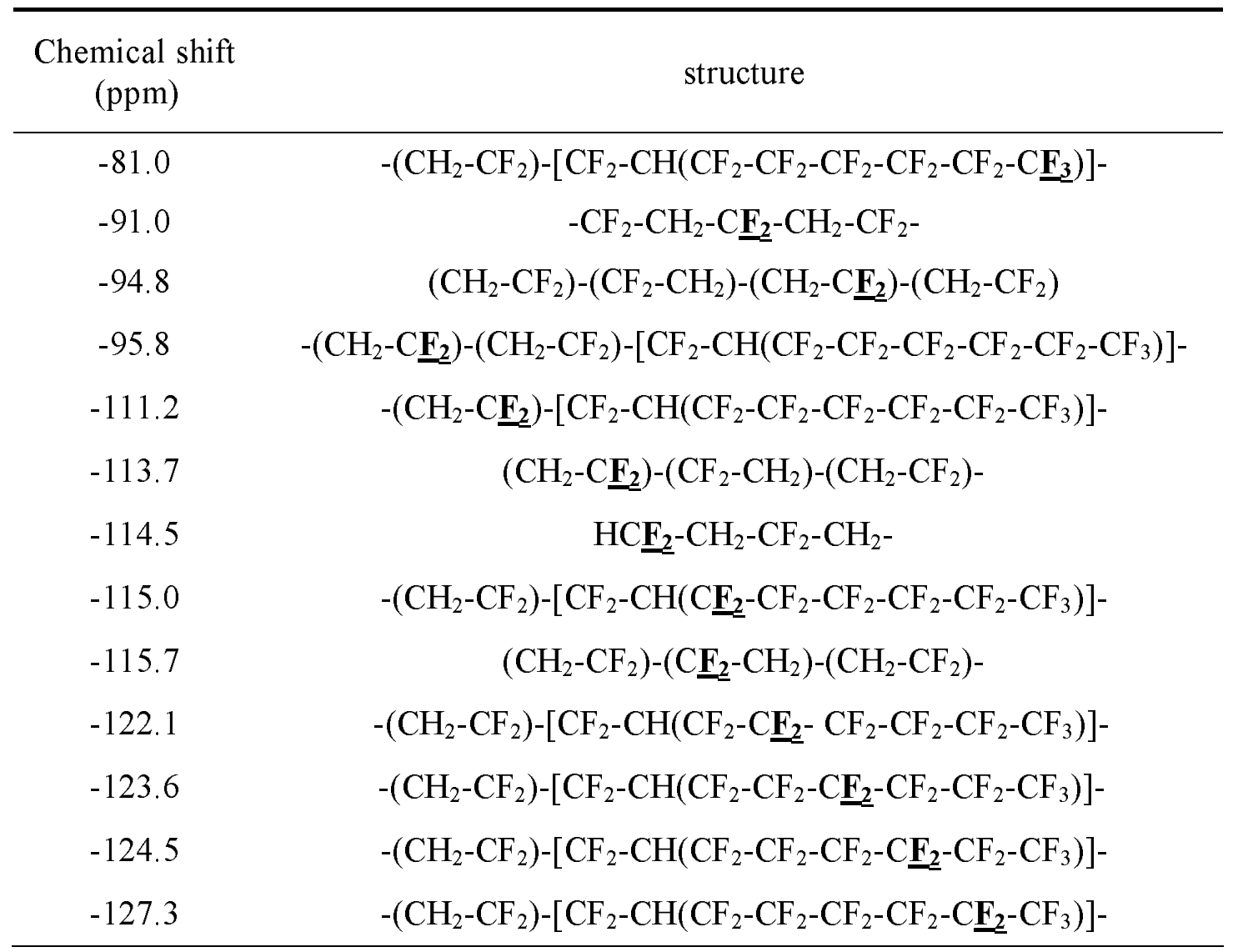

Table $3:{ }^{19} \mathrm{~F}$ NMR assignments of poly (VDF-co-HPO) copolymers. 


\begin{tabular}{|c|c|c|c|c|c|}
\hline Monomer B & $\mathbf{r}_{\mathrm{A}}$ & $\mathbf{r}_{\mathbf{B}}$ & $\mathbf{r}_{A} \mathbf{r}_{B}$ & $1 / \mathbf{r}_{\mathrm{A}}$ & Ref. \\
\hline $\mathrm{H}_{2} \mathrm{C}=\mathrm{CH}_{2}$ & 0.05 & 8.5 & 0.42 & 20.00 & {$[21]$} \\
\hline \multirow[t]{2}{*}{$\mathrm{H}_{2} \mathrm{C}=\mathrm{CHOCOCH}_{3}$} & -0.40 & 1.67 & -0.67 & -2.5 & [22] \\
\hline & 0.50 & 2.0 & 1.00 & 2.0 & [23] \\
\hline $\mathrm{H}_{2} \mathrm{C}=\mathrm{C}\left(\mathrm{CF}_{3}\right) \mathrm{CO}_{2} \mathrm{H}$ & 0.33 & 0 & 0 & 3.03 & [24] \\
\hline \multirow[t]{2}{*}{$\mathrm{FCH}=\mathrm{CH}_{2}$} & 0.17 & $4.2-5.5$ & $0.71-0.94$ & 5.88 & {$[25]$} \\
\hline & $0.20-0.43$ & $3.8-4.9$ & $0.76-2.11$ & $2.33-5.00$ & [26] \\
\hline $\mathrm{H}_{2} \mathrm{C}=\mathrm{CFCF}_{2} \mathrm{OR}_{\mathrm{F}}$ & 0.38 & 2.41 & 0.92 & 2.63 & [27] \\
\hline $\mathrm{F}_{2} \mathrm{C}=\mathrm{CFH}$ & 0.70 & 0.50 & 0.35 & 1.43 & [28] \\
\hline $\mathrm{F}_{2} \mathrm{C}=\mathrm{CHCF}_{3}$ & 9.0 & 0.06 & 0.54 & 0.11 & [13] \\
\hline $\mathrm{F}_{2} \mathrm{C}=\mathrm{CHC}_{6} \mathrm{~F}_{13}$ & 12.0 & 0.90 & 10.80 & 0.08 & Our work \\
\hline \multirow{2}{*}{$\mathrm{CFCl}=\mathrm{CF}_{2}$} & 0.73 & 0.75 & 0.55 & 1.37 & [29] \\
\hline & 0.17 & 0.52 & 0.09 & 5.88 & [30] \\
\hline $\mathrm{CFBr}=\mathrm{CF}_{2}$ & 0.43 & 1.46 & 0.63 & 2.33 & [29] \\
\hline \multirow{2}{*}{$\mathrm{CF}_{2}=\mathrm{CF}_{2}$} & 0.23 & 3.73 & 0.86 & 4.35 & {$[29,31]$} \\
\hline & 0.32 & 0.28 & 0.09 & 3.13 & [32] \\
\hline \multirow[t]{3}{*}{$\mathrm{CF}_{3}-\mathrm{CF}=\mathrm{CF}_{2}$} & 6.70 & 0 & 0 & 0.15 & [33] \\
\hline & 2.45 & 0 & 0 & 0.40 & [31] \\
\hline & 2.90 & 0.12 & 0.35 & 0.34 & [34] \\
\hline $\mathrm{F}_{2} \mathrm{C}=\mathrm{CFOCF}_{3}$ & 3.40 & 0 & 0 & 0.29 & {$[35]$} \\
\hline $\mathrm{F}_{2} \mathrm{C}=\mathrm{CFOC}_{3} \mathrm{~F}_{7}$ & 1.15 & 0 & 0 & 0.86 & {$[35]$} \\
\hline $\mathrm{F}_{2} \mathrm{C}=\mathrm{CFO}(\mathrm{HFP}) \mathrm{OC}_{2} \mathrm{~F}_{4} \mathrm{SO}_{2} \mathrm{~F}$ & 0.57 & 0.07 & 0.04 & 1.75 & [36] \\
\hline $\mathrm{CF}_{2}=\mathrm{CFCH}_{2} \mathrm{OH}$ & 0.83 & 0.11 & 0.09 & 1.02 & [37] \\
\hline $\mathrm{CF}_{2}=\mathrm{CF}\left(\mathrm{CH}_{2}\right)_{2} \mathrm{Br}$ & 0.96 & 0.09 & 0.09 & 1.00 & {$[38]$} \\
\hline $\mathrm{CF}_{2}=\mathrm{CF}\left(\mathrm{CH}_{2}\right)_{3} \mathrm{OAc}$ & 0.17 & 3.26 & 0.59 & 5.56 & [39] \\
\hline $\mathrm{F}_{2} \mathrm{C}=\mathrm{CF}\left(\mathrm{CH}_{2}\right)_{3} \mathrm{SAc}$ & 0.60 & 0.41 & 0.25 & 4.07 & {$[40]$} \\
\hline $\mathrm{CF}_{2}=\mathrm{CFCO}_{2} \mathrm{CH}_{3}$ & 0.30 & 0 & 0 & 3.33 & [41] \\
\hline $\mathrm{F}_{2} \mathrm{C}=\mathrm{C}\left(\mathrm{CF}_{3}\right) \mathrm{COF}$ & 7.60 & 0.02 & 0.15 & 0.13 & [42] \\
\hline $\mathrm{F}_{2} \mathrm{C}=\mathrm{C}\left(\mathrm{CF}_{3}\right) \mathrm{OCOC}_{6} \mathrm{H}_{5}$ & 0.77 & 0.11 & 0.08 & 1.30 & [43] \\
\hline
\end{tabular}

Table 4 : Monomer reactivity ratios for the copolymerisation of VDF (A) with other fluoroalkenes (B) (ethylene and vinyl acetate). 


\section{Figures Captions}

Figure 1: ${ }^{19} \mathrm{~F}$ NMR spectra (recorded in $\mathrm{CDCl}_{3}$ ) of 1-iodoperfluorohexane (uppest figure), 1-iodo-2,2dihydroperfluorooctane and 2-hydroperfluorooct-1-ene(HPO) (lowest figure) with expansion of the -71.6 to 73.8 ppm zone.

Figure $2:{ }^{13} \mathrm{C}$ NMR spectrum of 2-hydroperfluorooct-1-ene(recorded acetone $d^{6}$ ) with expansion of the 76.3 to $79.0 \mathrm{ppm}$ zone (the signal centred at $151 \mathrm{ppm}$ is assigned to the backfolding of the signal of carbonyl of acetone)

Figure $3:{ }^{19} F$ NMR spectrum of poly (VDF-co-HPO) copolymer (recorded in acetone $\left.d^{6}\right)$. Copolymerisation conditions: $[\mathrm{tBu}-\mathrm{OO}-\mathrm{CO}-\mathrm{tBu}]_{\sigma}\left([\mathrm{VDF}]_{0}+[\mathrm{HPO}]_{0}\right)=1 \mathrm{~mol} . \%, 74^{\circ} \mathrm{C}, 3$ hrs and $\mathrm{VDF} / \mathrm{HPO}$ initial molar ratio in the feed $=87.1 / 12.9$.

Figure 4 : Monomer-polymer composition curve from radical copolymerisation of VDF with HPO, calculated from ${ }^{19} \mathrm{~F}$ NMR. The full line represents the theoretical curve. 


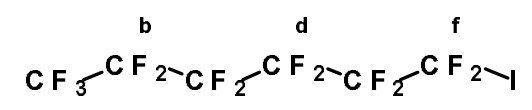

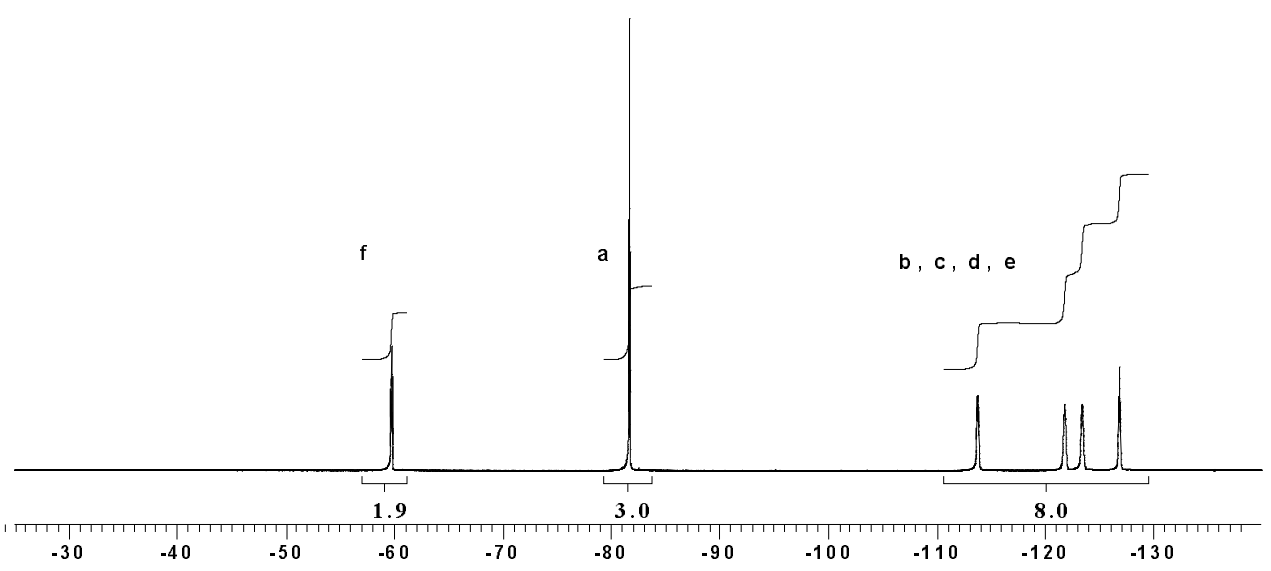

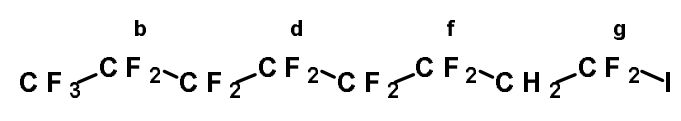

a
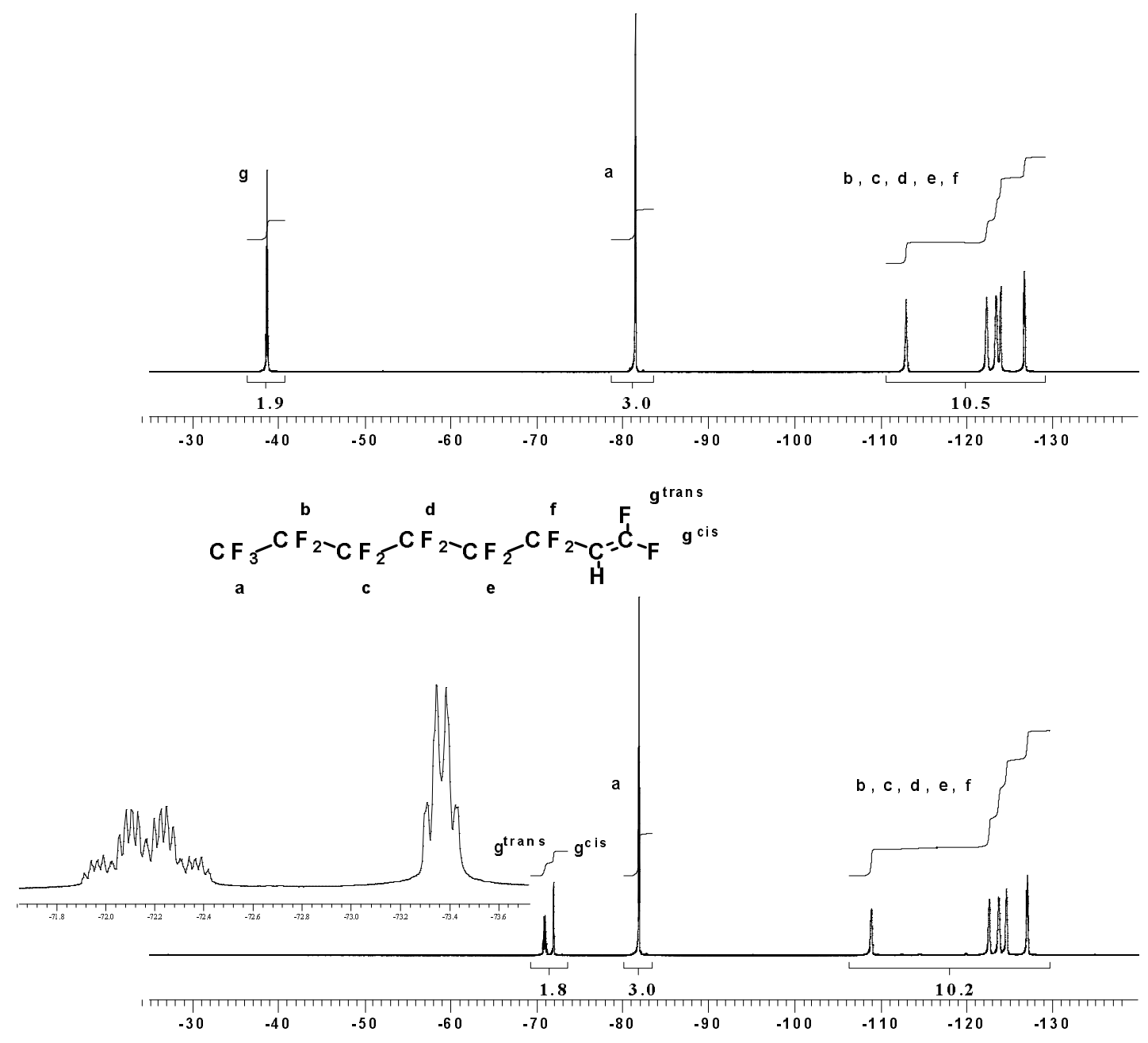

Figure 1: ${ }^{19} \mathrm{~F}$ NMR spectra (recorded in $\mathrm{CDCl}_{3}$ ) of 1-iodoperfluorohexane (uppest figure), 1-iodo-2,2dihydroperfluorooctane and 2-hydroperfluorooct-1-ene(HPO) (lowest figure) with expansion of the -71.6 to 73.8 ppm zone. 


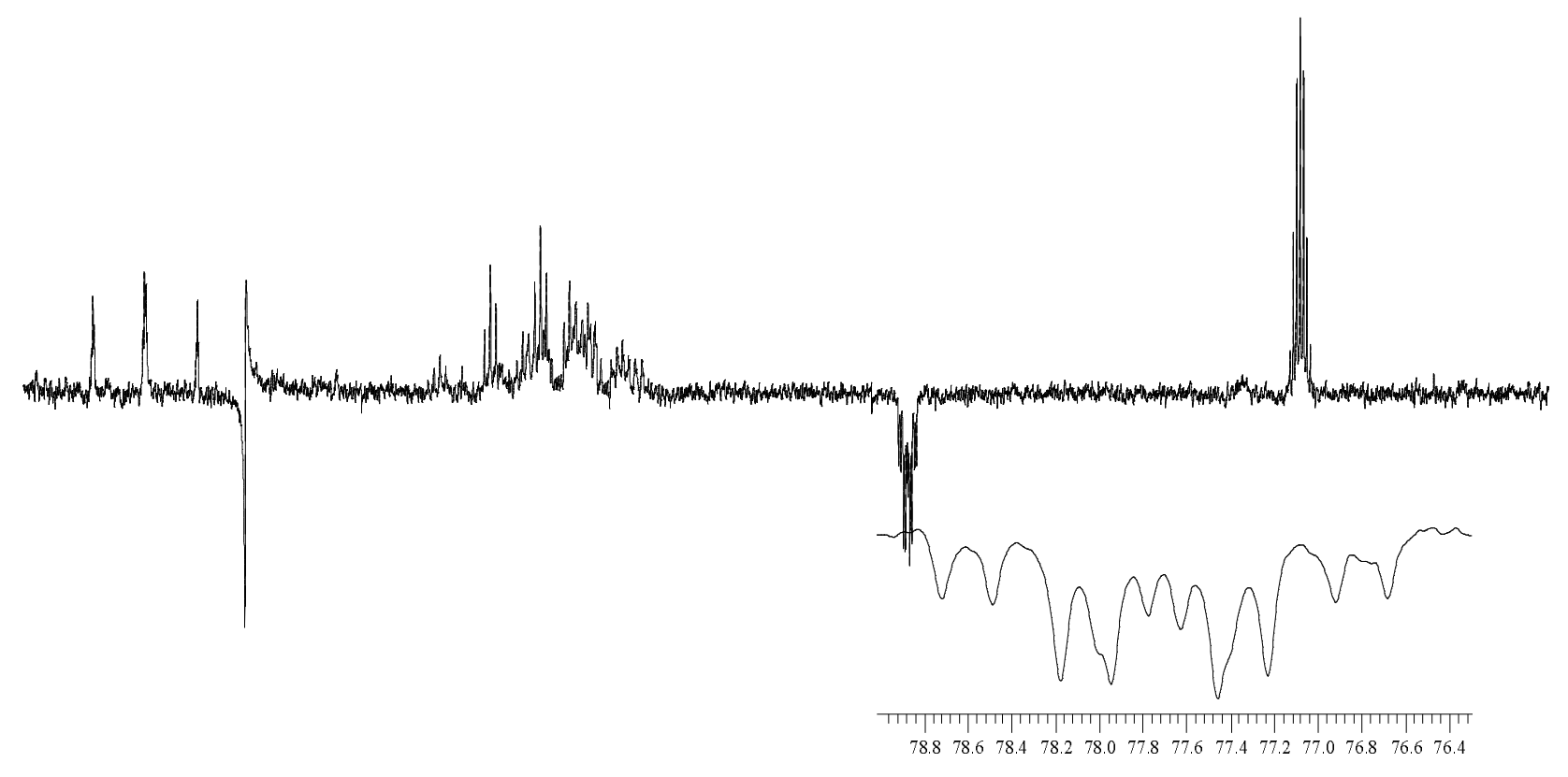

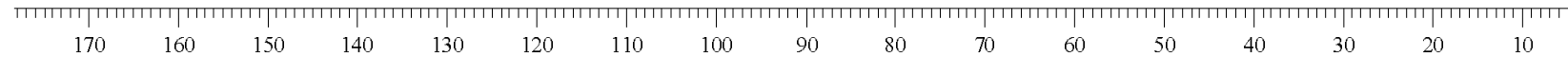

Figure $2:{ }^{13} \mathrm{C}$ NMR spectrum of 2-hydroperfluorooct-1-ene(recorded acetone $d^{6}$ ) with expansion of the 76.3 to $79.0 \mathrm{ppm}$ zone (the signal centred at $151 \mathrm{ppm}$ is assigned to the backfolding of the signal of carbonyl of acetone) 


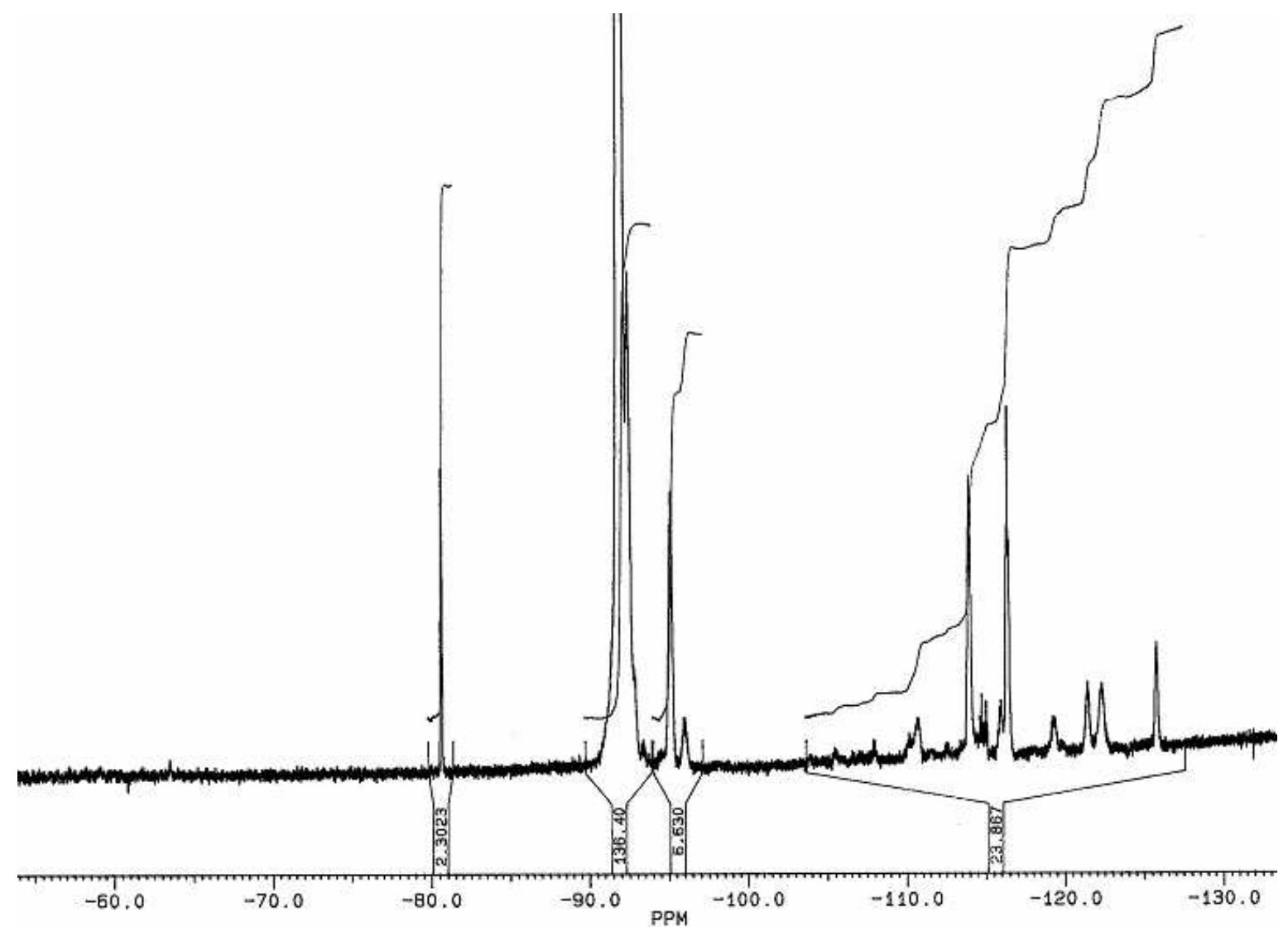

Figure $3:{ }^{19} F$ NMR spectrum of poly (VDF-co-HPO) copolymer (recorded acetone $d^{6}$ ). Copolymerisation conditions : $[\mathrm{tBu}-\mathrm{OO}-\mathrm{CO}-\mathrm{tBu}]_{0}\left([\mathrm{VDF}]_{0}+[\mathrm{HPO}]_{0}\right)=1 \mathrm{~mol} \%, 74^{\circ} \mathrm{C}, 3 \mathrm{hrs}$ and $\mathrm{VDF} / \mathrm{HPO}$ initial molar ratio in the feed $=87.1 / 12.9$. 


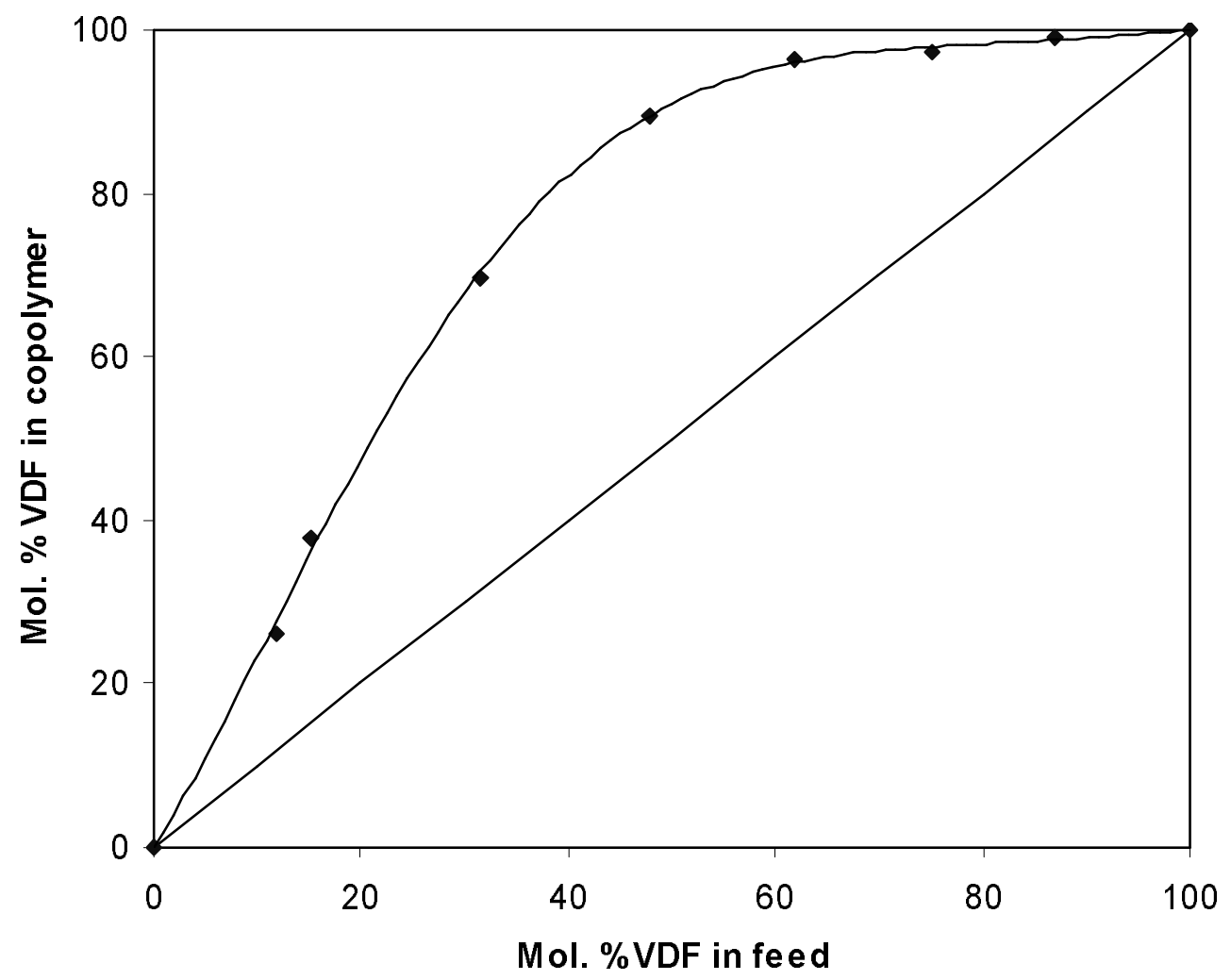

Figure 4 : Monomer-polymer composition curve from radical copolymerisation of VDF with HPO, calculated from ${ }^{19}$ F NMR. The full line represents the theoretical curve. 